\title{
Moralsk frihet og situasjon: Simone de Beauvoir
}

\author{
Tove Pettersen \\ Postdoc, dr. art, Etikkprogrammet/IFIKK, Universitetet i Oslo. \\ E-post: tove.pettersen@ifikk.uio.no
}

\begin{abstract}
Hvordan kunne Simone de Beauvoir allerede i 1949 skrive Det annet kjønn uten tilknytning til en kvinnebevegelse, og uten å oppfatte seg som feminist? Svaret er trolig at hennes mindre kjente moralfilosofi danner grunnlaget for senere analyser, og også forklarer utviklingen fra kjønnsblind ung filosof til radikal feministisk aktivist. Forbindelsen mellom Beauvoirs etikk og senere feministiske analyser viser dessuten hva som kan skje når idealistisk moralfilosofi møter en kjønnet virkelighet.
\end{abstract}

English abstract p. 327

Simone de Beauvoir (1908-1986) er mest kjent som forfatteren av Det annet kjønn, et verk som nå betraktes som en feministisk klassiker. Den filosofiske oppmerksomhet og anerkjennelse denne boken og andre deler av forfatterskapet fortjener, har imidlertid ikke kommet før relativt nylig. Særlig har utforskningen av etikken hennes vært forsømt. Langt på vei er det Beauvoirs moralfilosofiske refleksjoner som kulminerer i Det annet kjønn, for her anvender hun sin etiske tenkning om enkeltindividets frihet på kvinnens situasjon. Det er den filosofiske forbindelsen mellom Beauvoirs etiske tenkning, enkelte trekk ved Det annet kjønn, og hennes feministiske engasjement jeg vil eksponere i denne artikkelen. Hensikten er å synlig- gjøre hvordan en kjønnsblind moralfilosofi må nyanseres når den anvendes på en kjønnet virkelighet. Dessuten ønsker jeg å gjøre Beauvoirs etikk mer allment kjent. Hennes eksistensialistiske etikk handler om hvordan vi forvalter friheten $\mathrm{i}$ en verden uten forhåndsgitte regler og prinsipper, og er derfor også aktuell i vår verdipluralistiske samtid.

\section{FRA KJØNNSBLIND UNG FILOSOF TIL RADIKAL FEMINISTISK AKTIVIST}

Beauvoir var 41 år da Det annet kjønn kom ut, og før hun begynte på arbeidet med boken hadde hun knapt vist interesse for «kvinnesaken». Heller ikke i Det annet kjønn knytter Beauvoir seg selv eller sine te- 
orier til kvinnebevegelsen, og hun skrev verket uten særlig kontakt med kvinner som levde tradisjonelle liv. Selv om hennes analyse av kvinnen som det annet kjønn raskt fikk mye oppmerksomhet, gikk det faktisk over tyve år etter utgivelsen før hun offentlig erklærte seg som feminist. Det skjedde i november 1971, da hun engasjerte seg i kampen for selvbestemt abort. ${ }^{1}$ Etter denne første offentlige opptredenen, og i de siste 16 årene av livet hennes, var imidlertid feministiske spørsmål og feministisk aktivisme hennes hovedbeskjeftigelse.

Det er altså en tydelig utvikling hos Beauvoir: Hun blir mer og mer feministisk. Beauvoir er i utgangspunktet en apolitisk, afeministisk - nesten antifeministisk - ung filosof som identifiserer seg med sine mannlige filosofikollegaer og venner. I sin ungdom omgås hun hovedsakelig menn, og er en del av kretsen hvor filosofen Jean-Paul Sartre er hovedpersonen.

Hun er opptatt av de samme politiske sakene som Sartre, og overlater ofte politikken til ham. Mot slutten av sitt liv er hun imidlertid meget politisk bevisst og aktiv. Hun omgås først og fremst kvinner, og identifiserer seg eksplisitt med dem. Hun blir Frankrikes mest berømte intellektuelle kvinne, og får et internasjonalt navn. Hun er hovedperson i et miljø som langt på vei setter den politiske dagsorden, og det er særlig saker som angår kvinner hun fronter. Sagt på en annen måte: Beauvoir gjør Rousseaus ord om at man er radikal i sin ungdom og konservativ i sin alderdom til skamme. For Beauvoir er det omvendt: Hun går fra å være en kjønnsblind ung filosof på 1930-40-tallet til å bli en radikal feministisk aktivist på 1970-80-tallet.

Går vi mer systematisk til verks, kan tre faser identifiseres i forfatterskapet: Ungdomsfasen fra 1942-1947, som hun selv kaller sin etiske periode, kjennetegnes av kjønnsblindhet. I dette tidsrommet skriver hun flere essay og artikler om grunnleggende etiske problemer, blant annet om hvorvidt man kan etablere kriterier for riktig handling, skille etiske fra uetiske politiske prosjekter, og om vold kan begrunnes etisk. ${ }^{2}$ I sin filosofi tar hun utgangspunkt $i$ at mennesket er grunnleggende fritt, uten å tematisere kjønn. Heller ikke privat er hun særlig interessert i temaet. ${ }^{3}$ I en midtperiode fra ca. 1947-1971, som innledes når hun begynner arbeidet med Det annet kjønn, kommer erkjennelsen av at det finnes kjønnede maktstrukturer som innskrenker kvinnens handlingsrom og begrenser deres frihet. Likevel knytter hun seg ikke eksplisitt til kvinnesaken, og i Det annet kjønn er hun ambivalent til temaet. I den siste fasen fra 1971-1986 er hun imidlertid en dedikert og aktiv feminist. Hvordan kan denne utviklingen forklares?

\section{FILOSOFIEN SOM GRUNNLAG FOR FEMINISMEN}

En måte å forklare radikaliseringen på er å ta utgangspunkt i den filosofiske posisjonen hun utviklet i ungdomsfasen, og som hun langt på vei er tro mot gjennom hele sitt forfatterskap. Både hennes biografi og den historiske utviklingen av kvinnebevegelsen har sikkert også betydning, men denne sammenhengen er kommentert av flere andre. ${ }^{4}$ Langt mindre er sagt om hennes moralfilosofi og dens mulige innflytelse på levd liv. Dessuten innbyr hennes filosofiske posisjon til å brukes på denne måten.

Beauvoir er eksistensialist og fremhever at det er gjennom frie valg våre liv får mening. Med utgangspunkt i Beauvoirs egen filosofiske posisjon, fremstår det som underlig å anta at det var livets tilfeldigheter som gjor- 
de henne til feminist. Det er mer rimelig å tro at hun velger feminismen som prosjekt. Hvorfor velger hun akkurat dette prosjektet? Også her kan et svar finnes i hennes eksistensialistiske filosofi: Vi velger prosjekter med utgangspunkt i våre verdier. Den grunnleggende normative verdien i Beauvoirs filosofi er friheten, og jeg mener det er den samme friheten hun gjør til kjerneverdi også i sitt politiske engasjement. ${ }^{5} \mathrm{Vi}$ skal se nærmere på noen aspekter ved de tre periodene for å synliggjøre hvordan det normative standpunktet hun utvikler i den etiske ungdomsfasen spiller en sentral rolle også $\mathrm{i}$ de to andre periodene.

\section{BEAUVOIRS ETIKK}

Hovedtrekkene i Beauvoirs etiske tenkning blir utviklet mellom 1942 og 1946, og perioden avsluttes med utgivelsen av Tvetydighetens etikk (1947) som vi skal konsentrere oss om her. ${ }^{6}$ To tiår etter utgivelsen sier Beauvoir at dette er den teksten som irriterer henne mest, og Toril Moi gir henne rett i at det er grunn til å mislike den. Tvetydighetens etikk er, i følge Moi, dårlig oppbygd og lite overbevisende i sin argumentasjon. ${ }^{7}$ Fra et moralfilosofisk ståsted er imidlertid Tvetydighetens etikk et viktig verk. Én grunn er at Beauvoir utvikler et nytt frihetsbegrep nemlig begrepet moralsk frihet - som kommer i tillegg til begrepene ontologisk- og konkret frihet. ${ }^{8}$ Med utgangspunkt i begrepet om moralsk frihet blir Beauvoir i stand til å utvikle en eksistensialistisk etikk, og dette er et viktig moralfilosofisk bidrag fra Beauvoirs side. Tvetydighetens etikk var den gang det eneste verket som tilbakeviste beskyldingene om at eksistensialismen ikke kunne være utgangspunktet for en etikk. Likevel har Tvetydighetens etikk svakheter som senere vekker Beauvoirs irritasjon. Hun var misfornøyd, sa hun, fordi etikken var for idealistisk: Hun trodde, feilaktig, at

\section{Beauvoir trodde, feilaktig, at etikk kunne utformes utenfor en sosial kontekst.}

etikk kunne utformes utenfor en sosial kontekst. ${ }^{9}$ Dette poenget kan, slik jeg leser Beauvoir, utdypes ved å vise til at hun i Tvetydighetens etikk fremsetter en etikk som ikke bare kan karakteriseres som idealistisk, men også som kjønnsblind. Når Beauvoir senere blir oppmerksom på betydningen av kontekst, oppdager hun også den kjønnsblinde etikkens begrensinger. Kronologisk kommer Det annet kjønn rett etter Tvetydighetens etikk, og Beauvoir har selv påpekt en intendert kontinuitet. Den filosofiske sammenhengen består blant annet $\mathrm{i}$ at de moralfilosofiske innsiktene og begrepene hun utvikler i Tvetydighetens etikk, anvendes i Det annet kjønns analyse av undertrykking. ${ }^{10}$ Beauvoir utvikler sin moralfilosofi i Tvetydighetens etikk med utgangspunkt $\mathrm{i}$ at det ikke er noen moralsk relevante forskjeller mellom menn og kvinner. I Det annet kjønn blir hennes abstrakte moralfilosofi til analyseredskaper i undersøkelsen av empirien. Dette medfører at det sentrale og antatt kjønnsnøytrale begrepet om moralsk frihet må nyanseres når det anvendes i en kjønnet virkelighet. Når Beauvoir i Det annet kjønn kobler de moralfilosofiske innsiktene hun utvikler i Tvetydighetens etikk sammen med analysen av kvinners konkrete stilling, blir hun i stand til å skrive et verk som langt på vei legger det filosofiske grunnlaget for feminismen. Feminismen er en bevegelse med stor innflytelse både på enkeltindivider og på samfunnsutviklingen i vår del av verden. 
${ }^{11}$ Gjennom feminismen har Beauvoirs etikk hatt dyp innvirkning på vår kultur og situasjon etter andre verdenskrig. For å kunne få

\section{Beauvoirs etikk har hatt dyp innflytelse på vår kultur og situasjon etter andre verdenskrig.}

øye på denne sammenhengen, må vi imidlertid klarlegge noen av de filosofiske premissene som etableres i Tvetydighetens etikk.

\section{DET EKSISTENSFILOSOFISKE \\ GRUNNLAGET FOR BEAUVOIRS MORALFILOSOFI}

I første kapittel av Tvetydighetens etikk utlegger Beauvoir sitt syn på to grunnleggende aspekter ved menneskets situasjon: tvetydigheten og friheten. ${ }^{12}$ Én type tvetydighet beskrives ved å peke på at mennesket gjennom tenkning kan heve seg over sin naturbestemte undergang, erkjenne den i motsetning til dyr og planter, tenke igjennom sin egen død, men altså ikke fri seg fra den. Mennesket besitter også det privilegium at det er et suverent og unikt subjekt, men samtidig er det enkelte mennesket bare en liten del av et større fellesskap. Dette er eksempler på tvetydigheter i menneskets situasjon som medfører en permanent spenning og en kontinuerlig konfrontasjon med valgmuligheter. ${ }^{13}$

Det er to grunnleggende måter å respondere på eksistensvilkårenes tvetydighet: Enten kaste seg ut i verden og gripe mulighetene, eller trekke seg tilbake og flykte fra valgene. Dette er et uttrykk for to grunnleggende tendenser i mennesket. På den ene siden har mennesket en spontanitet, en drift, mot verden. I Tvetydighetens etikk kaller hun bevegelsen mot verden for å «avdekke væren», i Det annet kjønn bruker hun å «trans- cendere", å overskride. Begge utrykkene viser til at vi søker utover vår konkrete situasjon. I tilegg til behovet for å transcendere, har mennesket også trang til å unnfly frihetens krav, til å gi etter for «passivitetens og faktisitetens salighet». Beauvoir oppfordrer til et liv hvor vi ikke gir etter, men aktivt og bevisst bruker vår frihet. Det er et fritt og utadrettet engasjementet som, i en gudløs verden, gir livene våre mening. Hennes tanker om hvordan vi bør leve i en tvetydig og sekularisert verden - altså hennes etikk handler om hvordan vi forvalter denne friheten. For ikke alle frie valg er etiske valg.

\section{INAUTENTISKE VÆREMÅTER}

I Tvetydighetens etikk beskriver Beauvoir ulike måter å forholde seg til friheten på. Jeg skal gjennomgå de forskjellige væremåtene fordi de kan tydeliggjøre hva det vil si å forvalte friheten på en moralsk måte - til forskjell fra en ikke-moralsk eller en umoralsk bruk av friheten. Det er altså mulig å flykte fra friheten, og dermed fornekte den eksistensielle smerten knyttet til menneskets tvetydige situasjon. Beauvoir kaller dette flyktende mennesket for et sub-menneske. Det lever i ren faktisitet og er villig til å søke ly under en hvilken som helst ideologi eller etablert prinsipp. ${ }^{14}$ En annen inautentisk væremåte er å «bytte» friheten med noe absolutt; et moralsk prinsipp, eller en politisk idé som man er villig til å ofre både seg selv og andre for. I følge Beauvoir er dette den mest vanlige væremåten. Den som lever slik, kalles det seriøse mennesket. Hun kjennetegnes ved at friheten fornektes til fordel for et mål man betrakter som uforanderlig. Det er likegyldig hva målet er, bare man kan fortape seg i det. ${ }^{15}$ Det seriøse mennesket forsøker å realisere den umulige syntesen av $i$-seg-selv og 
for-seg-selv, og det er det seriøse livet for eksempel Ibsens Nora gjør opprør mot, skriver Beauvoir. ${ }^{16}$ Mister det seriøse mennesket

\section{Nihilisten har rett $\mathbf{i}$ at verden ikke har noen begrunnelse, men forstår ikke at det er opp til henne selv å begrunne sitt liv.}

sitt mål, er hun tilbake til sub-menneskets stadium. Om den seriøse mislykkes, kalles hun nibilisten i Beauvoirs verk. Nihilisme er skuffet seriøsitet vendt mot seg selv, skriver hun videre. Nihilisten definerer eksistensen som en mangel på mening og innhold, og dette skuffer. Men eksistensen er ikke, i følge Beauvoir, en mangel. Nihilisten har rett i at verden ikke har noen begrunnelse, at hun selv ikke er noe, men forstår ikke at det er opp til henne selv å begrunne sitt liv. Nihilisten ser ikke at friheten er et mål i seg selv, og opplever ikke det tvetydige ved menneskets situasjon som mulighet, men som mangel. Eventyreren ser derimot tvetydigheten som et positivt aspekt, og fryder seg over å leve til tross for fravær av forhåndsbestemt mening. Eventyreren kaster seg ivrig inn i nye prosjekter - det være seg erobringer, kriger, forskning, eller kjærlighet. Hadde eksistensialismen vært solipsistisk, ville eventyreren vært en helstøpt helt, sier Beauvoir. ${ }^{17}$ Det positive med eventyreren er overskridelsen av det gitte, og at friheten betraktes som en mulighet. Det problematiske er likegyldigheten i forhold til prosjektets innhold. Eventyreren bekrefter sin eksistens gjennom relasjoner til andre, men tar likevel ikke inn over seg hvilken betydning og verdi andre mennesker har. Dermed har eventyreren samme forakt overfor andre mennesker som nihilisten. Antitesen til eventyreren er det lidenskapelige mennesket. Den lidenskapelige vender seg nettopp mot prosjektets innhold (for eksempel kjærligheten eller ideologien), men får et nærmest manisk forhold til det. Den lidenskapelige vil eie og besitte, og streber etter å fange det hun brenner for i skjebnen til $i$-seg-selv. ${ }^{18}$ Derfor kan ikke frihet få sin genuine form her heller.

Alle de beskrevne måter å leve på er inautentiske. I tilfeller hvor den utadrettete bevegelsen mot verden avskjæres, slik tilfellet er med sub-mennesket, lever man inautenisk fordi man forblir i immanensen. I eksistensial-

\section{Snakker vi om en eksistensial-} istisk etikk, er det å transcendere ikke tilstrekkelig.

ismen synes man å foretrekke den som transcenderer, slik blant annet eventyreren gjør, fordi man da tar ansvar for å skape mening og verdier i eget liv. ${ }^{19}$ Mange oppfatter også dette som eksistensialismens kjernepunkt - å bruke friheten til å velge egne prosjekter. Men snakker vi om en eksistensialistisk etikk, er det å transcendere ikke tilstrekkelig. Det er bare ett skritt på vei mot den autentiske væremåten som Beauvoir i Tvetydighetens etikk kaller den moralske. Den beauvoirske etikken strekker seg altså lenger enn å oppfordre til å skape mening med eget liv - dens etiske kjernepunkt er at vi også må ta ansvar for hva slags prosjekter vi velger å engasjere oss $\mathrm{i}$.

\section{DET MORALSKE MENNESKET - DEN AUTENTISKE VÆREMÅTEN}

Den som setter friheten selv som høyeste mål, og ikke et fritt valgt prosjekt, kaller Beauvoir i Tvetydighetens etikk for det genuint frie mennesket. Dette mennesket har moralsk frihet; det lever autentisk. Det genuint 
frie og autentiske mennesket kjennetegnes ved å være bevisst sin egen frihets virkelige krav - som er å ville seg selv. Det betyr at man må ville forbli fri. Det kan bare skje ved å destinere seg selv mot en åpen fremtid. Man må ikke begrense friheten gjennom valg som fører til ufrihet. Beauvoir presiserer at friheten ikke er noe vi har, det er en kontinuerlig bevegelse. ${ }^{20}$ Når friheten «vil seg selv», innebærer det også at den vil utvide seg selv gjennom andres frihet. Derfor må andres frihet respekteres og hjelpes frem. Beauvoir har flere argumenter for dette, blant annet at ingen kan virkeliggjøre sin frihet uten i relasjon til andre. $\AA$ ha friheten selv som høyeste mål, kan kalles metanormen i Beauvoirs eksistensialistiske frihetsetikk. Normen fungerer som en lov som setter grenser for handling, og som samtidig gir seg selv et innhold. ${ }^{21}$ Et menneske som handler slik, er et virkelig fritt menneske fordi hun forvalter friheten moralsk. ${ }^{22}$ Dette står i kontrast til den som ikke tar andres frihet med i beregningen, som bruker andre som midler, eller ødelegger dem som begrenser eget handlingsrom.

Mange har kritisert eksistensialismen for at man innen dens rammer og $\mathrm{i}$ frihetens navn kan gjøre hva som helst til verdi. Vi ser at denne kritikken ikke rammer Beauvoir. Forklaringen er at hun innfører begrepet moralsk frihet i tillegg til begrepene om ontologisk og konkret frihet. Ontologisk fribet

\section{Å velge å undertykke eller skade andre er nettopp ikke en moralsk forvalting av friheten.}

kan forstås som viljesfrihet, en frihet også den undertrykte beholder. Sartre har særlig fremholdt dette: Vi er frie også i tvangssituasjoner. Vi kan for eksempel velge hvordan vi vil møte døden. ${ }^{23}$ Den konkrete fribeten viser til vår faktiske situasjon og det handlingsrom vi har, det vil si hvor mye makt vi har til å iverksette våre beslutninger og valg. Konkret frihet kan i motsetning til ontologisk frihet innskrenkes. Den som har tilstrekkelig med konkret frihet kan selvsagt også velge handlinger og verdier som undertrykker og skader andre. Men å velge å undertrykke eller skade andre er nettopp ikke en moralsk forvalting av friheten. Hovedtesen i Beauvoirs etikk er at vi må ta et moralsk ansvar både for egen og andres frihet en tese som leder til standpunktet om at undertrykking er galt. Det er nettopp dette som kommer til uttrykk i Det annet kjønn.

\section{MORALSK FRIHET I ET \\ KJØNNSPERSPEKTIV}

Det annet kjønn legger til grunn en antagelse fra Tvetydighetens etikk, nemlig at kvinner og menn i utgangspunktet er like både i forhold til behovet for å transcendere, og fristelsen til å trekke seg tilbake i immanensen. ${ }^{24}$ I Det annet kjønn viser Beauvoir imidlertid hvordan en kjønnet kultur påvirker disse tendensene hos menn og kvinner i ulik retning. ${ }^{25}$ Kvinnens frie og spontane bevegelse mot verden blir innskrenket: «For et stort antall kvinner er transcendensens veier sperret", sier hun. ${ }^{26}$ I Det annet kjønn beskrives konkrete situasjoner hvor kvinner blir avskåret fra muligheten til å overskride sin situasjon. Kvinner blir enten tvunget til et liv i immanensen, eller de velger å akseptere begrensningene. A akseptere ufrihet er imidlertid en flukt fra friheten, og Beauvoir kritiserer derfor kvinner for å leve inautentisk. Samtidig fremhever hun også hvordan fristelsen til å godta en tilværelse i immanensen er mye større for kvinner. I Det annet 
kjønn anklager Beauvoir kvinner for å være medskyldig i sin undertrykkelse, og oppfordrer dem til selv å ta et oppgjør med sin situasjon. Denne oppfordringen bygger på hennes etikk: Det er et etisk krav å befeste sin egen subjektivitet. Men for mange kvinner betyr iverksettelsen av dette etiske kravet en overvinnelse av fristelsen til å innkassere de fordeler det gir å være «mannens medløper». ${ }^{27}$ Det kan nemlig ha store for-

\section{Den som er sulten, syk og under- kuet kan ikke transcendere og ta ansvar for sitt eget liv slik den mer heldigstilte kan.}

deler både eksistensielt, sosialt og økonomisk å innta rollen som den andre. ${ }^{28}$ Dette har moralske implikasjoner: Fordi hun stadig er fristet med minste motstands vei, er hennes kostnader ved å leve autentisk langt større enn mannens. ${ }^{29}$

Her hører vi gjenklangen av påstanden $\mathrm{i}$ Tvetydighetens etikk om at «etikk er frihetens seier over faktisiteten». ${ }^{30}$ Samtidig ser vi at appliseringen av dette etiske kravet leder til erkjennelsen av at å "seire over faktisiteten» innebærer noe helt annet for mennesker som har fått sin konkrete frihet innskrenket. Konkret frihet kan tas fra oss ved bruk av vold, manipulering og gjennom fattigdom. Den som er sulten, syk og underkuet kan ikke transcendere og ta ansvar for sitt eget liv slik den mer heldigstilte kan. Sammenlignet med Det annet kjønn er Tvetydighetens etikk idealistisk fordi Beauvoir ikke innreflekterer dette forholdet mellom frihet og situasjon i sin etikk. I Tvetydighetens etikk bemerker hun riktignok at kvinner som er innelåst $\mathrm{i}$ et harem har begrensede muligheter til overskridelse ${ }^{31}$ - et eksempel hun i selvbiografien Moden alder forteller at hun brukte som moteksempel i en diskusjon med Sartre om hans frihetsbegrep. ${ }^{32}$ Likevel synes hun å ta for gitt at (vestlige) kvinner har nok konkret frihet til å kunne overskride sin situasjon.

Når Beauvoir analyserer kvinners situasjon under arbeidet med Det annet kjønn, erkjenner hun å ha undervurdert kvinneundertrykkingens omfang og rekkevidde. I Tvetydighetens etikk skriver hun om «mystifikasjon» som redskap for undertrykkelse. Det er først i Det annet kjønn hun blir klar over hvor mektig undertrykkingen er, og hvordan den berøver kvinner deres subjektivitet og hindrer transcendens. Det annet kjønn kan leses som en beskrivelse av kjennetegn ved den moralske frihetens motsats, nemlig ufrihet, uærlighet og undertrykkelse. En person er undertrykt når hun er avskåret

\section{Både undertrykker og under- trykte i Beauvoirs etikk er forhindret fra å oppnå moralsk frihet.}

fra å ha en egen fremtid, for det er en fritt valgt fremtid som gir mening til nåværende eksistens. Andre kan gi handlingsrom og åpne fremtiden, men de kan også lukke den og begrense subjektets situasjon. Vår ontologiske frihet kan ikke tas fra oss, men andre kan altså kontrollere vår situasjon. Blir den konkrete friheten begrenset, innskrenkes også muligheten til å utvikle moralsk frihet. ${ }^{33}$ I Det annet kjønn viser Beauvoir hvordan en fri fremtid systematisk blir lukket for kvinner, og at både menn og kvinner derfor ikke kan utvikle moralsk frihet. Både undertrykker og undertrykte i Beauvoirs etikk er forhindret fra å oppnå moralsk frihet, fordi ingen av dem lever som "genuint frie mennesker». De har ikke satt, eller kan 
ikke sette, friheten som høyeste mål. Dette er et av Det annet kjønns sentrale poeng.

\section{INAUTENTISK TRANSCENDENS}

Sammenlignet med kvinnen er mannens situasjon beskrevet i Det annet kjønn som kjennetegnet ved større konkret frihet, og bedre muligheter til transcendens. Frihet og transcendens er verdifullt for Beauvoir, men samtidig er menn også undertrykkere. Hvordan kan menn som lever slik Beauvoir betrakter som etterstrebelsesverdig samtidig være undertrykkere? Leser man Det annet kjønn isolert kan den fremstå noe kontradiktorisk, fordi Beauvoir synes å beundre de undertrykkerne hun kritiserer. Tidvis kan boken fremstå som filosofisk mangelfull fordi hun ikke eksplisitt argumenterer for hvorfor det er moralsk galt å undertrykke andre. Det å gjennomanalysere en undertrykkende situasjon, er ikke det samme som å levere normative argumenter for hvorfor situasjonen bør endres. Beauvoir har imidlertid gitt en utførlig normativ begrunnelse i Tvetydighetens etikk, og hennes beskrivelse der av autentiske og inautentiske levemåter kaster lys også over mannens moralske situasjon i Det annet kjønn.

Det som kjennetegner det genuint frie og moralske mennesket i Tvetydighetens etikk er bevisstheten om frihetens virkelige krav om å ville seg selv. ${ }^{34}$

Den som ikke anerkjenner egen og andres frihet, den som undertrykker og begrenser friheten, lever ikke moralsk i folge Beauvoirs etikk. Dette er undertrykkerens situasjon i Det annet kjønn. De menn som der figurerer i bakgrunnen kan være eventyrere og leve den lidenskapelige, den seriøse eller den nihilistiske manns liv. Men selv om menn transcenderer, er det altså ikke nød- vendigvis moralsk autentisitet knyttet til denne bevegelsen. På samme måte som vi finner ulike former for frihet i Beauvoirs fi-

\section{Å transcendere er ikke ensbe- tydende med å ta et moralsk ansvar for friheten.}

losofi, finnes det også ulike former for transcendens. Å transcendere er ikke ensbetydende med å ta et moralsk ansvar for friheten. En undertrykker forvalter ikke sin frihet på en moralsk måte, og lever dermed ikke autentisk. Hans brist er å ikke sette friheten som høyeste verdi. ${ }^{35}$

\section{GJENSIDIG ANERKJENNELSE AV FRIHETEN}

I Tvetydighetens etikk er Beauvoir opptatt av gjensidigheten mellom egen og andres frihet. Muligheten til å legitimere egne livsprosjekter er avhengig av andre frie mennesker, og dette er én av grunnene til å ville andres frihet. I Det annet kjønn sier hun:

Det er tilstedeværelsen av de andre menneskene som river mennesket ut av dets immanens og gjør at det kan virkeliggjøre sitt sanne vesen, som en higen mot objektet, som prosjekt. Men denne fremmede friheten, som bekrefter min frihet kommer også i konflikt med den; det er den ulykkelige bevissthetens tragedie at enhver bevissthet streber etter å hevde seg som eneste, herskende subjekt. ${ }^{36}$

Første setning bygger på den grunnleggende ontologiske antagelsen om behovet for å avdekke væren og delta i meningsfulle prosjekter i relasjon til andre. Denne antagelsen spiller en viktig rolle i begge verkene. I siste 
setning fremheves imidlertid det problematiske ved mellommenneskelige relasjoner, og betoningen av dette er mye sterkere i Det annet kjønn. Likevel forstås ikke forholdet mellom mennesker som en kamp om overtaket hvor utfallet enten er at man vinner og hersker over den andre, eller taper og blir behersket. Hos Beauvoir er det ikke slik at «Helvete - det er de andre». Det finnes nemlig en mulig løsning på konflikten mellom bevissthetene: «Dramaet kan overkommes ved at man fritt anerkjenner den andre som individ, at enhver setter seg selv og den andre som objekter og subjekter i en gjensidig bevegelse», sier hun. ${ }^{37}$ Spørsmålet er imidlertid hvordan vi kan oppnå gjensidig anerkjennelse av hverandres frihet. Hun svarer

\section{Hos Beauvoir er det ikke slik at «Helvete - det er de andre».}

på dette i Det annet kjønn, ved å si at det krever dygder: Mennesket må besitte dygder av typen vennskap og storsinnethet. Å fremvise det vennskapet og den storsinnetheten som konkret virkeliggjør anerkjennelsen av friheter, er menneskets ypperste prestasjon, det er resultatet av en kamp som krever at mennesket kontinuerlig overvinner seg selv, sier hun. Når hun så vil formulere dette gjensidighetspoenget på en annen måte enn ved å vise til karakterdygder, griper hun tilbake til tesen i Tvetydighetens etikk om det genuint frie og moralske mennesket:

Man kan uttrykke det på en annen måte og si at mennesket når en autentisk moralsk holdning når det gir avkall på å være og tar ansvar for sin eksistens; gjennom denne omvendelsen, gir det også avkall på ethvert eierskap, for det å eie er en måte å søke væren på, men den omvendelsen som fører til at mennesket når virkelig visdom er aldri fullført, den må stadig foretas, den krever en konstant anstrengelse. ${ }^{38}$

Dette å også skulle gi «avkall på eierskap» kan forstås som at man i tillegg til å transcendere også må sette friheten som høyeste verdi: Man oppgir å dominere andre. Vi ser at moralfilosofien fra Tvetydighetens etikk i Det annet kjønn brukes som en appell om å oppgi eierskap - den ligger til grunn for oppfordringen om å bekjempe undertrykking. Den beauvoirske etikken er ikke bare opptatt «selvrealisering», men peker direkte (mer enn mange andre etikker) mot politisk handling: Å leve etisk innebærer også å ta politisk stilling. ${ }^{39}$ Motstand mot undertrykking og støtte til frigjøring er det politiske budskapet som følger fra den etiske hovedtesen i Tvetydighetens etikk. ${ }^{40}$ Men det er altså ikke før den eksistensialistiske frihetsetikken anvendes på kvinnens situasjon at Beauvoirs politiske engasjement for alvor begynner å utvikle seg. I hennes filosofi kommer dette til uttrykk blant annet ved at hun i Det annet kjønn innreflekterer det faktum at noen menneskers mulighet til frihet er meget begrenset.

\section{NøLINGEN I Det annet kjønn}

Det annet kjønn kan altså leses som en beskrivelse av frihetens motsats, en situasjon hvor både undertrykker og undertrykte ikke oppnår moralsk frihet. Selv om det er mulig å vise en sammenheng mellom den filosofiske posisjonen hun utviklet i sin tidlige fase og Det annet kjønn, tilkjennegir Beauvoir også en sterk ambivalens når det gjelder «kvinnesaken». Det annet kjønns første setning er: "Jeg har nølt lenge med å skrive en bok om kvinnen. Emnet er irriterende, sær- 
lig for kvinner, og det er ikke nytt». Likevel skriver hun altså en murstein om dette «irriterende» emnet. På innledningens første side

\section{Det ville være påfallende mangelfullt å sette frihet som høyeste verdi uten å si at det er galt å bruke denne friheten til å undertrykke andre.}

omtaler hun også kvinnene som «de» «hvilken plass har de i verden, hvilken plass burde de ha?» spør hun. ${ }^{41}$ Hun skriver her om kvinner som om hun ikke skulle være en av dem. ${ }^{42}$ Det er en avstand mellom Beauvoir selv og den situasjon som hun nådeløst analyserer. Beauvoir forklarer denne avstanden i et intervju i 1972 - ved å si at hun er privilegert. Hun har vært heldig i forhold til andre kvinner fordi hun har unnsluppet det hun kaller kvinners trelldom: Moderskapet og husmorlivet. I tillegg fikk hun ta en filosofisk utdannelse, slik at hun ble anerkjent for sitt intellekt. ${ }^{43}$ Beauvoir betraktet seg altså som en eksepsjonell og privilegert kvinne - og sett i lys av hennes historiske og kulturelle situasjon, har hun rett. Kanskje er denne posisjonen også en del av forklaringen på hvorfor hun kunne analysere kvinners situasjon så klart og presist.

Det annet kjønn fremstår altså som langt mer feministisk enn det Beauvoir gav uttrykk for at hun selv var på denne tiden. ${ }^{44}$ Ikke bare beskriver hun kvinnens situasjon, hun tar også standpunkt: Kvinnens situasjon er undertrykt, ufri og urettferdig, og den må endres om kvinnene skal kunne leve som frie mennesker. Dette er et normativt standpunkt som utvilsomt følger fra den moralfilosofien hun utvikler i sin etiske periode. Å sette frihet som høyeste verdi uten å si at det er galt å bruke denne friheten til å undertrykke andre, ville være påfallende mangelfullt.

\section{HVA SLAGS FEMINISME?}

Hva slags feminisme er det egentlig Beauvoir fremsetter i Det annet kjønn? Hun forkaster moderskapet og husmorrollen, hun oppfordrer til økonomisk uavhengighet, men hun lanserer ingen detaljerte alternativer. Hennes biograf Bair og andre har antydet at hun burde foreslå andre levemåter når hun «fratar» kvinner deres tradisjonelle roller. ${ }^{45}$ Med utgangspunkt i hennes eksistensialistiske frihetsfilosofi lar imidlertid også fraværet av en innholdsrik plan for fremtidens kvinner seg forklare: Et av hennes

\section{Når Beauvoir avviser moderskapet og husmorrollen er det fordi disse rollene giør kvinner ufrie.}

grunnleggende eksistensfilosofiske poeng er at vi er frie til selv å velge hvordan vi vil leve våre liv, og at det er en etisk forpliktelse å selv ta dette ansvaret, samt forvalte friheten på en ansvarlig måte. Om Beauvoir hadde kommet med en oppskrift på en alternativ levemåte, ville det stride mot hennes tanke om at hver især må skape sitt eget liv. Hun bebreider dem som ukritisk overtar konvensjoner og tradisjoner, for å leve inautentiske liv. Hadde Beauvoir pekt ut én vei ville hun ha begrenset valgmulighetene, og dermed lukket fremtiden for andre kvinner.

Det Beauvoir gjør i Det annet kjønn er først og fremst å analysere patriarkalske maktstrukturer som begrenser kvinners frihet. Når hun avviser moderskapet og husmorrollen er det fordi disse rollene gjør kvinner ufrie, og begrenser deres valgmulig- 
heter. Nå kan man innvende at hjemmetilværelsen er innholdsrik, og at barn kan være et fritt valgt og meningsfylt prosjekt. Dette er en vanlig innvending mot Beauvoir; at hun devaluerer tradisjonelle kvinnelige verdier. ${ }^{46}$ Hun har også blitt beskyldt for å forherlige mannen og det som forbindes med det mannlige. ${ }^{47}$ Men en verdivurdering er ikke hennes poeng. Poenget er at hun i Det annet kjønn, med utgangspunkt i sin moralfilosofi, viser hvordan de tradisjonelle kjønnsrollene gir mannen stor konkret frihet, og samtidig gjør kvinnen til den ufrie andre.

\section{REAKSJONER PÅ Det annet kjønn}

For kvinner som opplevde 1950-tallets familieideologi og erfarte ekteskapet og moderskapet som undertrykkende, var Det annet kjønn viktig. Den gang var dette den eneste boken som kritisk analyserte kvinners situasjon. ${ }^{48}$ Mange reagerte imidlertid også negativt. I løpet av 1960-tallet fikk Beauvoir mye kritikk fra kvinnebevegelsen som den gang vokste frem. Selv om boken hadde dyp innflytelse på mange kvinner, var det mange som betvilte at Beauvoir var feminist. Beauvoir fikk hatefull kritikk fra noen, mens andre demonstrativt ignorerte henne. ${ }^{49}$ Verken Hélène Cixouse, Luce Irigaray eller Julia Kristeva nevner Beauvoir i sine tidlige tekster. ${ }^{50}$ Den feministiske teorien som vokste frem i Frankrike på 1970-tallet er den såkalte forskjellsfeminismen. Forskjells-

\section{Identitet og kjønnsforskjeller er sekundære i forhold til situasjon.}

feministene er opptatt av kjønnsidentitet og kjønnsforskjeller. De gjør forskjellen til utgangspunkt, og søker å bevare og oppvurde- re denne forskjellen. Dette er fjernt fra Beauvoirs måte å tenke på. For Beauvoir blir en kjønnet identitet skapt gjennom handling og valg - «man fødes ikke som kvinne, man blir det». Det finnes ingen gitt kjønnsidentitet. Identitet og kjønnsforskjeller er sekundære i forhold til situasjon, og de kjønnsforskjeller som finnes har bare den verdien som kulturen tillegger dem. ${ }^{51}$ Beauvoir har sagt at de som tar utgangspunkt $\mathrm{i}$ at kvinner er essensielt forskjellige fra menn, spiller menns spill. Det eksisterer en biologisk forskjell mellom kvinner og menn, men denne er ikke grunnlaget for de sosiologiske forskjellene. ${ }^{52}$ En kvinne er for Beauvoir et menneske med en bestemt type biologi, en biologi som ikke gjør henne underlegen, ${ }^{53}$ men heller ikke overlegen. På samme måte som Beauvoir nekter å godta at en kvinne er mindre verdt enn en mann fordi hun er født med kvinnekjønn, nekter hun også å godta at dette kjønnet skulle gjøre henne bedre. Hun anerkjenner at det er en forskjell (og er derfor ingen «likhetsfeminist»), men hun gir ikke denne forskjellen samme betydning som det de såkalte forskjellsfeministene gjør. ${ }^{54}$

\section{FILOSOFI OG POLITISK AKTIVISME}

Gjennom både levd liv og hennes forfatterskap har vi sett at Beauvoir gjennomgår en politisk radikalisering. Vi har sett at den eksistensialistiske etikken fra Tvetydighetens etikk kan skape sammenheng mellom de tre fasene. Et gjennomgående trekk i alle periodene er at hun henvender seg direkte til enkeltindividet. Det er «den konkrete andre» hun er opptatt av, ikke "den universelle andre». I Tvetydighetens etikk tar hun ikke utgangspunkt i en bestemt etisk teori, men henvender seg til hver især som moralske ve- 
sener. Hun appellerer til at vi som enkeltindivider ikke ukritisk må adoptere konvensjoner, blant annet fordi det fratar oss vårt individuelle ansvar. I Det annet kjønn skriver hun ikke på vegne av en bestemt feministisk teori eller bevegelse, hun henvender seg til den enkelte kvinne og oppfordrer dem til å handle. Appellen til det ansvarlige enkeltindividet er en eksistensialistisk grunntanke hun aldri slipper. Den kommer til uttrykk også i den siste perioden av hennes liv hvor hun ikke ville slutte seg til én bestemt gruppering. Beauvoir støttet saker som tilsynelatende var motsigelsesfulle; det har blitt hevdet at hun nesten var anarkistisk i sin holding til ulike saker og bevegelser. ${ }^{55}$ Likevel har alt hennes politiske engasjement en fellesnevner: Avvisningen av enhver ideologi, gruppe eller ledelse som ville begrense friheten. Fra 1970 og frem til sin død tok hun, på vegne av forfulgte borgere, til motmæle mot alle regjeringer som førte en undertrykkende politikk. ${ }^{56}$ I dette politiske engasjementet hører vi ekkoet fra hennes filosofiske utlegning om friheten som høyeste verdi. De siste årene av sitt liv viet hun til politisk aktivisme. Hun sluttet nesten å skrive filosofi, og deltok i stedet i film og TV-produksjoner, fordi disse mediene når et større publikum. Også her finner vi et unikt trekk ved Beauvoir - vi har å gjøre med en filosof som fremsetter en filosofi så handlingsorientert at den leder henne bort fra den akademiske fagfilosofien og ut i verden som engasjert feministisk aktivist.

\section{Noter}

I Dette engasjementet foregikk blant annet ved at 343 kvinner, inkludert Beauvoir, den 5 april 1971 skrev under på en erklæring om at de alle hadde
Det er mange grunner til å studere Beauvoirs etikk. Én er at det i moralfilosofien er sjeldent med kvinnestemmer, og derfor god grunn til å lytte til hva hun har å si. En annen grunn er at hun tenker etikk på en måte som er forskjellig fra den tradisjonelle moralfilosofen, og som ikke så lett lar seg innplassere i det etiske landskapet. Hennes etikk kan ver-

\section{Den filosofiske grunntanken om at mennesket er fritt og ansvarlig er ingen utdatert radikalisme.}

ken klassifiseres som deontologi, utilitarisme eller dygdsetikk. Den forbindelsen hun skaper mellom individuell etikk og politisk engasjement er også viktig fordi mye av den dominerende etikken er svært akademisk og har få koblinger til politisk aktivitet. Det samme kan sies om feminismen. Også hennes fokusering på eget ansvar, egne valg og individuell frihet gjør hennes etikk viktig: Den filosofiske grunntanken om at mennesket er fritt og ansvarlig er ingen utdatert radikalisme, men høyst relevant enten man lever under totalitære og udemokratiske regimer eller i en postmoderne, nyliberalistisk verden. I en tid med verdipluralisme er Beauvoirs fokus på betydningen av å finne egne verdier og veier både tankevekkende og inspirerende. Samtidig trekker Beauvoir en nødvendig etisk grense både $\mathrm{i}$ forhold til hvor langt man kan gå $\mathrm{i}$ utfoldelsen av egen frihet, og for hvor ignorant man kan være overfor andres undertrykkelse.

tatt abort, noe som var forbudt i Frankrike. Beauvoir sier i 1982 at det ikke var sant, men hun skrev under av politiske grunner. Se Bair, Deirdre: 
Simone de Beauvoir. A Biography. New York: Touchstone 1991, s. 547. Manifestet førte til stor skandale, men 4 år senere ble abort lovlig. Se Rowley, Hazel: I tykt og tynt. Trondheim: Damm 2005, s. 329. Manifestet kan forøvrig beskues på http://www.bok.net/pajol/manif343.html (TP 29.10.2006). Den observante leser vil finne andre kjente navn på listen, deriblant Arlette Elkaïm (Sartres adoptivdatter), og Hélène de Beauvoir (Simone de Beauvoirs søster).

2 Hun publiserer også romaner i denne perioden, og hennes første roman L'invitée kom i 1943. I 1944 gir hun ut det moralfilosofiske essayet $P y r$ rhus et Cinéas, og i 1945 kommer romanen Le Sang des autres. Skuespillet Les Bouches inutiles settes opp i 1945, og i 1946 foreligger romanen Tous les hommes sont mortels. Hun publiserer også flere artikler i denne perioden, og i 1946 publiserer hun flere artikler som i 1947 utgis samlet i det moralfilosofiske verket Pour une morale de l'ambiguité.

3 Fullbrook, Edward and Fullbrook, Kate: Simone de Beauvoir. A Critical Introduction. Cambridge: Polity Press 1998, s. 24, 120-121. Bair 1991, s. 654-655.

4 Beauvoirs biograf Deirdre Bair forstår Beauvoirs sterke engasjement delvis som et påskudd for å slippe å ta inn over seg Sartres sykdom, og viser til at Beauvoir beskrev deltakelsen i feminismen som «sendt fra gudene» i den perioden hun "så Sartre dø litt for hver dag som gikk». Se Bair 1990, s. 572. Også Toril Moi gir i sine bøker om Simone de Beauvoir en presentasjon av Beauvoir hvor biografien langt på vei brukes til å forklare filosofien. Når det gjelder utviklingen av fransk feminisme, se for eksempel Duchen, Claire: Feminism in France. London: Routledge \& Kegan Paul 1986.

5 Det innebærer at jeg mener Beauvoirs forfatterskap og tenkning preges av konsistens. Noen filosofer og forfattere kjennetegnes ved brudd, vi kan for eksempel snakke om den unge og den eldre Sartre, den tidlige og den sene Heidegger. Beauvoir er ikke, slik jeg leser henne, en slik filosof; det finnes en grunnidé gjennom hele hennes forfatterskap

6 Dette essayet, Pour une morale de l'ambiguité, er ikke oversatt til norsk, men finnes i en engelsk versjon med tittelen The Ethics of Ambiguity, og $i$ en svensk oversettelse För en tvetydighetens moral. Det ville være mer korrekt å kalle verket For en tvetydighetens moral, men jeg velger å følge
Toril Moi som kaller essayet Tvetydighetens etikk, og som er forholdsvis innarbeidet på norsk. Det er imidlertid problematisk å oversette «moral» med «etikk», særlig hos Beauvoir, men dette problemet kan ikke utdypes her.

7 Moi, Toril: Simone de Beauvoir. En intellektuell kvinne blir til. Oslo: Gyldendal Norsk Forlag 1995, s.169-170.

8 De ulike frihetsbegrepene blir forklart senere i artikkelen.

9 Moi 1998, s. 169.

Io Dette poenget gjør også andre, blant annet Arp, Kristina :The Bonds of Freedom. Simone de Beauvoir's Existentialist Ethics. Illinois: Open Court 2001, s. 142-145, Heinämaa, Sara: «The body as instrument and as expression» i Claudia Card (ed.) The Cambridge Companion to Simone de Beauvoir.Cambridge: Cambridge University Press 2003, s. 75, Gothlin, Eva: «Simone de Beauvoir (1908-1986). Kvinnen - det annet kjønn» i Rustad, Linda og Bondevik, Hilde (red.) Kjønnsperspektiver i filosofihistorien Oslo: Pax forlag 1999, s. 234.

I I Fullbrook \& Fullbrook 1998, s. 100.

I 2 Dette er en beskrivelse av hva Beauvoir oppfatter som ontologiske trekk ved menneskets situasjon både friheten og tvetydigheten er gitt.

I3 Beauvoir, de Simone. 1976. The Ethics of Ambiguity. New York, A Citadell Press book.s. 7. Heretter referert til som EA.

I4 EA, s. 44-45.

I 5 EA, s. $46-47$.

I6 EA, s. 48.

I7 EA, s. 57-59.

I8 EA, s. 67.

I9 $\mathrm{Vi}$ berører her et sentralt punkt i all moralfilosofi, nemlig spørsmålet om hvordan verdier oppstår. Eksistensialismens svar er at det verken er Gud, tradisjoner, konvensjonene eller autoriteter som skaper moralske verdier, men mennesket selv som frembringer verdier gjennom sine frie valg.

20 EA, s. 28.

2 I Pettersen, Tove: «Frihet som høyeste verdi: Simone de Beauvoirs etikk.» Morgenbladet 07.04.2006.

22 EA, s. 60-61.

23 Pettersen, Tove. «Frihetsfilosofiens vedvarende aktualitet: Jean-Paul Sartre (1905-80)». Aschehoug og Gyldendals Store Norske årbok 2006. Oslo: Kunnskapsforlaget 2006, s. 269-271.

24 «Ved siden av subjektets autentiske krav, som er uinnskrenket frihet, finnes hos det eksisterende 
vesen en inautentisk lyst til å trekke seg tilbake og flykte; det er passivitetets salighet». Beauvoir, de Simone. Det annet kjønn. Oslo: Pax Forlag 2000, s. 359. Heretter referert til som DAK.

${ }_{25}$ Se også Wiestad, Else: «Moderne feministisk teori. Eksistensialistisk feminisme: Simone de Beauvoir» i (Hareide m.fl. red.) Larebok i filosofihistorie. Oslo: Det Norske Samlaget 1996, s. 526 533, og Wiestad, Else: «Kjønn, frihet og kunnskap» i (Ariansen m.fl. red.) Larebok i filosofiog vitenskapshistorie. Oslo: Unipub, s. 199-203. 26 AK, s. 318.

27 DAK, s. 40-41.

28 DAK, s. 40,41,359.

29 DAK, s. 193.

$30 \mathrm{EA}$, s. 44.

3 I EA, s. 38.

32 Beauvoir de, Simone: Moden alder, Oslo: Pax

Forlag A/S 2004, s. 419.

33 Arp 2001, s. 115.

34 EA, s. 28.

35 EA, s. 63.

36DAK, s. 197.

37 DAK, s. 198.

38 DAK, s.198.

39 Arp 2001, s. 112-113.

40 Mer om Beauvoirs politiske tenkning og engasjement finnes i bl.a. Marso, Jo Lori og Moynagh, Patricia (eds.): Simone de Beauvoir's Political Thinking. Chicago: University of Illinois Press 2006.

4I DAK, s. 33. Hun sier riktignok litt senere: «Hvis jeg vil definere meg selv, er jeg nødt til først og erklære. «Jeg er en kvinne»; denne sannheten danner den bakgrunnen som enhver annen påstand trer frem på» DAK, s. 35. For en interessant analyse av dette se Moi, Toril: Jeg er en kvinne. Det personlige og det filosofiske. Oslo: Pax forlag 2001, del II.

42 Senere bekrefter Beauvoir dette inntrykket, og forklarte at hun mente at hun hadde unnsluppet kvinners situasjon. Bair 1991, s. 383.

43 Men, har hun sagt, nå når det er så mange kvinnelige filosofistudenter er mennene redde for å miste sin posisjon. Se Fullbrook \& Fullbrook, s. 119.

44 Det er likevel noe bemerkelsesverdig her, siden det påstås at hun faktisk møtte profilerte feminister. Se Fullbrook \& Fullbrook, s. 24, Bair 1991, 654-655, og Beauvoirs fjerde selvbiografi Tout compte fait publisert i 1972.

45 Bair 1991, s. 556.
46 Denne innvendingen bygger også på manglende forståelse for den historiske konteksten verket ble til i. I Frankrike på 1940-50-tallet var det, i følge Toril Moi, nærmest umulig for kvinner å ha både familie og et yrke, det franske velferdsstaten var ikke etablert. Før 1965 kunne ikke franske kvinner åpne egen bankkonto eller ta jobb uten at ektemannen samtykket. Prevensjon ble ikke lovlig før 1967, og før 1970 hadde gifte kvinner ikke formell foreldrerett over sine barn. Forbudet mot abort varte frem til 1974. Se Moi 1995, 211-212. ${ }_{47}$ Beauvoir har blant annet blitt beskyldt for å bruke en maskulin målestokk og utgangspunkt når hun gjør seg opp en mening om hva som er verdifullt. Frihetsbegrepet hennes blir anklaget for å være maskulint og representativt for en vestlig kapitalistisk sexistisk etikk (Mary Evans sitert i Moi 1995 s. 205), og at den transcendens, kreativitet og handling som Beauvoir oppfordrer til er maskuline dygder (Jean Leighton sitert i Brison, Susan: «Beauvoir and feminism: interview and reflections» i Card 2003, s.198).

48 Moi 1995, s. 204.

49 På dette tidspunktet tok Beauvoir ikke til motmæle mot kritikken, og hun fortsatt å følge Sartre på hans mange reiser blant annet til Sovjetunionen og Latin-Amerika. Dessuten har, i følge Bair, de fleste av hennes offentlige uttalelser fra denne tiden preg av et «me-too» som gjorde mange av dem som mente hun burde løsrive seg fra Sartre rasende. Bair 1991, s. 546.

5० Bair 1991, s. 553, Moi 1995, s. 206-207, Brison 2003, s. 198-200.

5I Moi 1995, s. 225.

52 Bair 1991, s. 551.

53 Brison 2003, s. 203

${ }_{54}$ Siden Beauvoir ikke selv kalte seg feminist da hun skrev Det annet kjønn knytter mye av vår kjennskap til hennes feministiske posisjon seg fra intervjuer på 1970-80 tallet. Et interessant spørsmål er om hun endret syn. Om dette har hun sagt at de grunnleggende teoretiske premissene i Det annet kjønn stod fast, men at hun endret syn når det gjaldt taktikk og praksis. Se Brison 2003, s. 199. Et eksempel er at hun i Det annet kjønn mener at kvinner må slutte seg til sosialismen fordi hun antok at den sosialistiske endringen vil medføre samfunnsmessige forandringer som også vil frigjøre kvinnen. Så sent som i 1966 kalte hun seg radikal feminist. Men i 1976 sier hun at hennes syn forandret seg da hun (og andre kvinner) oppdaget at menn av 68-generasjonen ikke behand- 
let dem som likeverdige. Beauvoir sier hun forsto at kvinner ikke kunne forvente at deres frigjøring skulle komme fra en generell revolusjon, eller at kvinner automatisk skulle bli frigjorte i et sosialistisk samfunn. Kvinner må selv skape den end- ringen de ønsker seg, fremholdt Beauvoir. Se Bair 1991, s. 555, Brison 2003, s. 202.

55 Brison 2003, s. 200.

56 Bair 1991, s. 550-552. 